\title{
Influence of sea temperature, substratum and wave exposure on rocky intertidal communities: an analysis of faunal and floral biomass
}

\author{
C. D. McQuaid and G. M. Branch \\ Zoology Department, University of Cape Town, Rondebosch 7700, South Africa
}

\begin{abstract}
Effects of sea temperature regime, substratum type and degree of wave exposure on the composition of rocky intertidal communities in the Cape of Good Hope were examined using cluster analyses of data for biomass of 310 species on 12 rocky shores. The Cape of Good Hope forms an overlap area between the south and west coast intertidal biota of South Africa (Stephenson, 1939) and species composition was found to be largely influenced by temperature regime, species richness being greatest within the area of overlap. However, biomass is dominated by very few species, the 10 species with highest biomass on each beach accounting for an average of $92 \%$ of total biomass. If the 10 species exhibiting greatest biomass on each of the 12 beaches considered are pooled, a total of only 45 species is involved; 25 of these reveal biomass trends in response to gradients of wave exposure. Thus, while temperature regime establishes, by exclusion, a framework of species composition on each beach, the actual biomass of the species present is largely influenced by degree of exposure. Cluster analyses based on biomass data reveal groupings based primarily on the degree of exposure and secondarily on temperature. While specific influences of substratum (especially of substratum instability) were apparent, any overall effects on the biota were masked by those of exposure and temperature.
\end{abstract}

\section{INTRODUCTION}

Intertidal communities are affected by a wide range of physical factors including the effects of wave action, sea temperature and substratum. Considerable effort has been directed towards an understanding of the influence of these factors on intertidal populations. Temperature has long been recognised as a major factor governing species distribution (e.g. Isaac, 1938; Stephenson, 1944; Lewis, 1964) and mechanisms for this have been examined by Southward (1955, 1958), Crisp (1957), and Lewis (1964) amongst many others. Stability of substratum is obviously important and various properties of the substratum may lead to significant differences in the populations present (e.g. Barnes and Powell, 1950; Stephenson, 1961; Williams, 1964; Harlin and Lindbergh, 1977; Sousa, 1979). Likewise the degree of wave action can have important effects on the community (e.g. Kingsbury, 1962; Dayton, 1971; Hällfors et al., 1975) and relative abundance of common species on various shores may be used as a biological scale for wave exposure (e.g. Ballantine, 1961; Taylor, 1971).
The Cape of Good Hope forms an area of overlap between the south and west coast intertidal biota of South Africa (Stephenson, 1939), the east coast of the Cape Peninsula experiencing much warmer sea temperatures than the west coast which is cooled by summer upwelling. Rocky shores in the peninsula may be formed by Cape granite, Malmesbury shale or Table Mountain sandstone, which have different degrees of hardness and which weather in characteristic forms, while outcrops of extremely soft, semi-consolidated beach rock occur along the northern shore of False Bay (Fig. 1). In the present study the interplay of the influences of temperature, substratum and degree of exposure on rocky intertidal communities was examined on a quantitative basis. Twelve rocky shores were selected which covered a range of combinations of temperature, substratum and exposure. The effects and relative importance of these physical parameters to the intertidal communities selected were analysed in terms of their influence on species composition and biomass as well as the richness and diversity of the communities. 


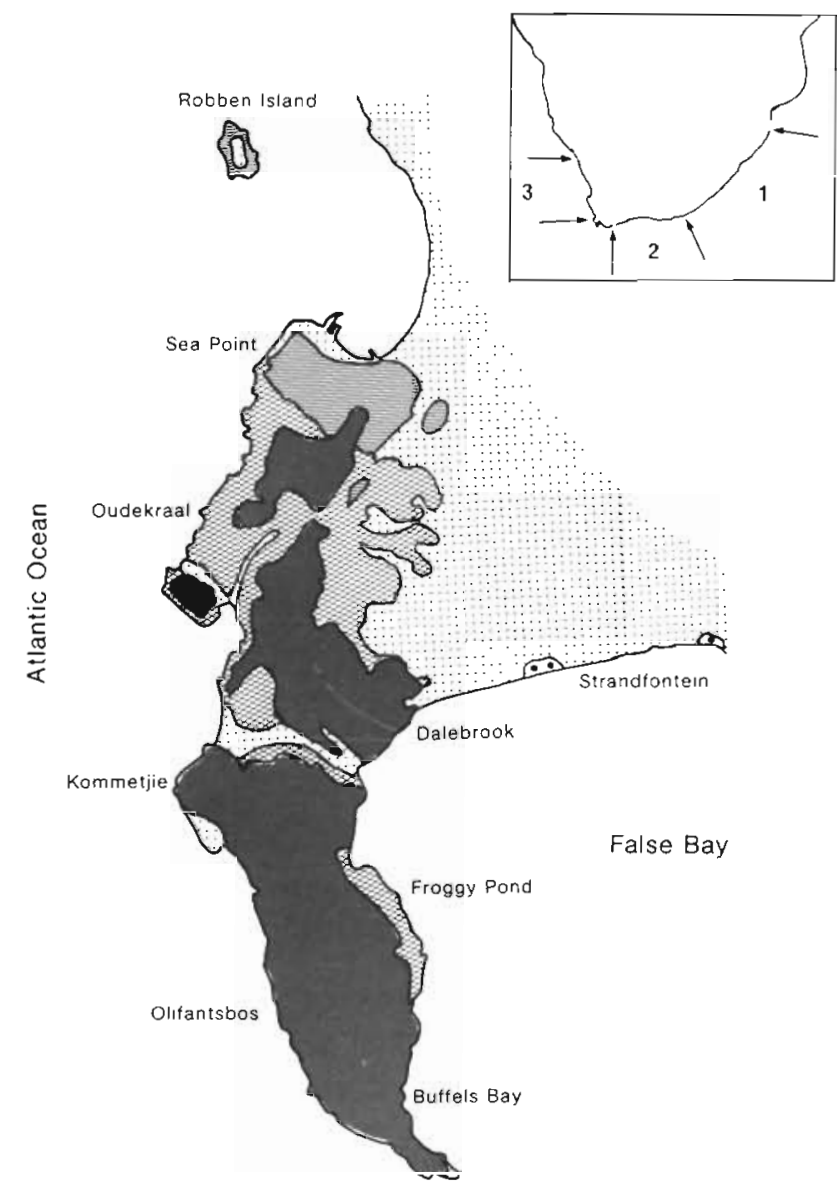

Fig. 1. Study sites in the Cape of Good Hope. Dots: sand deposits; closed circles: beach rock; horizontal shading: shale; cross-hatching: granite; solid shading: sandstone. Areas 1 to 3 (inset) indicate the 3 intertidal biota of southern Africa recognised by Stephenson (1939), the Cape of Good Hope forming an overlap area between south and west coast biota

\section{STUDY SITES}

Physical conditions on the 12 beaches examined are summarized in Table 1 . They include 6 beaches on the west coast of the peninsula and 6 on the east coast. Sea temperatures on the east coast of the Cape Peninsula show marked seasonality with high summer temperatures (approximately 16 to $19^{\circ} \mathrm{C}$ ) and low winter temperatures $\left(12.5\right.$ to $\left.14^{\circ} \mathrm{C}\right)$. On the west coast winter temperatures are fairly constant at 11 to $13^{\circ} \mathrm{C}$. Rapid perturbations are caused in summer by frequent upwelling of cold water $\left(9\right.$ to $\left.10^{\circ} \mathrm{C}\right)$ and occasional tongues of warm water $\left(20\right.$ to $21^{\circ} \mathrm{C}$ ) sweeping around Cape Point from the east (Fricke and Thum, 1975). Three of the shores examined on each coast were exposed to heavy wave action and three were sheltered. Exposure categories were assessed subjectively and independently by 3 individuals, prior to sampling, on the basis of the position of each rocky shore and its orientation with respect to the predominant swell directions Wherever possible exposed and sheltered shores closely adjacent to one another were compared.

Three rock types form intertidal substrates in the Cape Peninsula. Table Mountain sandstone has a small grain size (composed of quartz grains cemented by silica) and lies in almost horizontal beds. It weathers into large blocks and generally forms broad, gently sloping beaches. Malmesbury shale is formed from silt and clay particles and has a very small grain size. It lies in almost vertical beds and weathers into jagged parallel ridges running towards the sea and separated by deep gulleys. Shale usually forms gently sloping beaches and occurs only on the west coast. Cape granite is the only local igneous rock and is coarsegrained with a rough surface. It occurs as huge exhumed boulders forming very steep or vertical beaches where intertidal pools rarely occur.

\section{METHODS}

Although the number of individuals of each species present on a beach is important, patterns of energyflow through a community are generally more significantly influenced by biomass values. Dendrogram analyses were therefore performed on species biomass data.

These were derived by mapping the communities or species assemblages occupying the major zones and sub-zones on each shore (an average of 10 on each shore) using aerial photographs in combination with field observations. Initial observations using multiple samples of $0.01 \mathrm{~m}^{2}$ revealed that cumulative samples of $0.5 \mathrm{~m}^{2}$ included between 90 and $100 \%$ of the species present in each community. Each community was, therefore, randomly sampled by collecting all organisms in duplicate $0.25 \mathrm{~m}^{2}$ quadrats, sorting them to species level and then determining biomass by drying to constant weight at $60^{\circ} \mathrm{C}$. Species exhibiting clumped distribution and large, uncommon species were sampled separately using belt transects. Heavily calcified species (molluscs, large crustaceans, echinoids, barnacles) were acidised in 1 molar $\mathrm{HNO}_{3}$ to remove inorganic materials before drying. Lengthweight regressions were derived for some of the larger common species and weights subsequently calculated from shell measurements.

Whereas intra-shore comparisons have frequently been made between communities or zones on the same shore, we wished to make quantitative inter-shore comparisons where separate shores were considered as entities. As the zones found on each rocky shore differ both in absolute size and in their relative contribution 
to total intertidal area on different shores, comparisons were based on mean species biomass for each shore as a whole

This was derived by considering the proportion that each zone formed of the entire intertidal area. This proportion formed a weighting factor by which the average biomass of each species within each zone was multiplied. Total mean biomass for each species for the whole shore was then obtained by summing the weighted biomass for each zone. In this way, data for 112 identified communities were reduced to a matrix of mean biomass of 310 species on 12 shores.

\section{ANALYSIS}

The matrix of biomass data was subjected to cluster analysis using the Czekanowski coefficient (Bray and Curtis, 1957), which excludes double zero matches, as a measure of similarity. The main clustering techniques have been reviewed by Williams (1971) and Clifford and Stephenson (1975) and the polythetic group average strategy was used following Field et al. (1982). Biomass values were subjected to log transformation before analysis (Field and MacFarlane, 1968; Field, 1971) to prevent swamping of the data by high values. Indicator species characterising the 3 physical factors considered were examined using the information statistic or I-test on presence/absence data (Field, 1969). The arbitary cut-off value used to distinguish indicator species corresponds to $\mathrm{P}<0.05$ (Field et al., 1982). Significant differences in biomass of each species between the beaches sampled were examined using the non-parametric Mann-Whitney U-test (Siegel, 1956).

Diversity has 2 aspects: species richness and species evenness. Richness (S) was measured directly and evenness $(\mathrm{J})$ derived as:

$$
\mathrm{J}=\frac{\mathrm{H}}{\log \mathrm{S}}(\text { Pielou, 1969) }
$$

where $\mathrm{H}=$ Shannon-Weaver index of diversity. $\mathrm{H}$ is calculated as:

$$
H=-C \sum_{j} P_{j} \log _{e} P_{j} \text { (Pielou, 1969) }
$$

where $\mathrm{P}_{\mathrm{j}}=$ probability of a randomly chosen individual from the sample being species $\mathrm{j}_{\text {; }} \mathrm{C}$ was taken to be $\mathrm{l}$ following Pielou (1969). H may be influenced by certain properties of the data themselves and can be used only for data on a common taxonomic level, e.g the species (Hughes, 1978).

\section{RESULTS}

\section{Cluster analysis}

The dendrograms provided illustrate the results of group-average cluster analyses on biomass data for the rocky shores investigated. Fig. 2 is based on the full data matrix for all 12 shores. The shores separate into

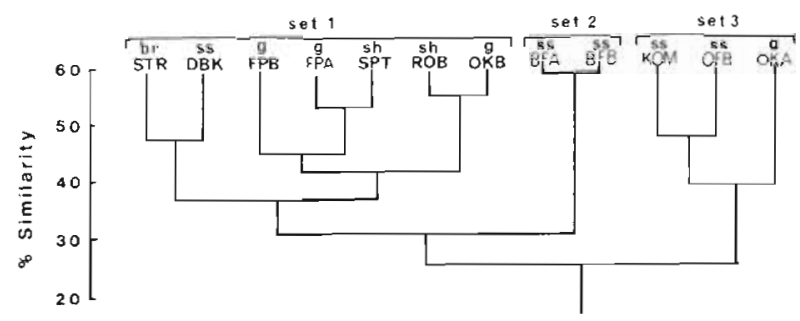

Fig. 2. Results of group-average dendrogram analysis of data for 310 species on 12 rocky beaches in the Cape of Good Hope (see Table 1 for abbreviations of beach names) br: beach rock; g: granite; sh: shale; ss: sandstone. Exposed beaches are in bold type in all dendrograms

3 sets relating primarily to differences in temperature and exposure at the sites but exhibiting no pattern which may be related to the nature of the substratum. Clustering into sets occurs firstly on the basis of exposure (with the single exception of Froggy Pond A) and secondly on the basis of temperature: Set 1: Warm and cold exposed shores (with the exception of FPA); Set 2: paired warm water, sheltered, Buffel's Bay sites; Set 3: cold sheltered shores.

In order to examine the relative significance of temperature, exposure and rock type, sites differing only in terms of 2 of these factors were compared. If only sedimentary shores are considered, sites with comparable temperature and exposure are most closely linked (Fig. 3 B). Limited conclusions can be drawn about the igneous sites (Fig. 3 A) as there were only four but the

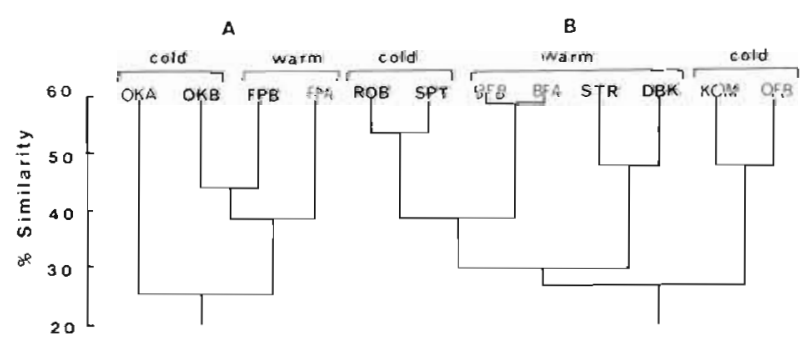

Fig. 3. Results of dendrogram analysis of data. A: igneous beaches only; B: sedimentary beaches only

closest clustering is between the 2 exposed sites Oudekraal B (west coast) and Froggy Pond B (east coast). If warm or cold shores are considered separately (Fig. 4 A, B) grouping occurs on the basis of exposure (with one exception, Froggy Pond A). Likewise, when 
exposed or sheltered shores are analysed independently (Fig. 5 A, B), they group according to temperature (again with one exception, Froggy Pond B). In

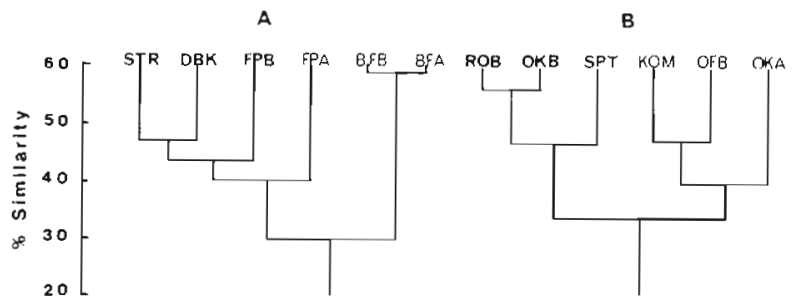

Fig. 4. Results of dendrogram analysis of data. A: warm water beaches only (i.e. False Bay); B: cold water beaches only (west coast)

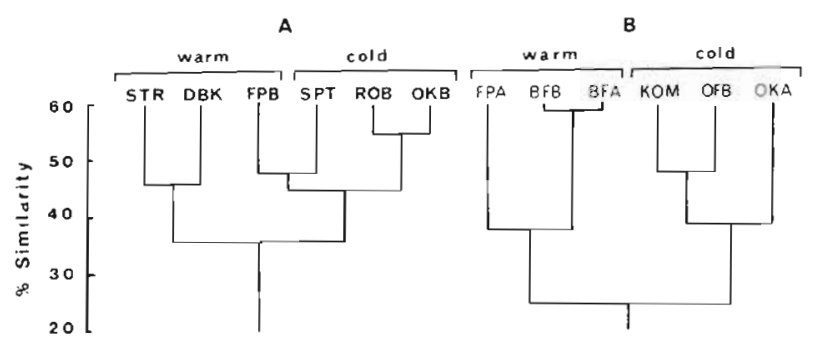

Fig. 5. Results of dendrogram analysis of data. A: exposed beaches only; $B$ : sheltered beaches only

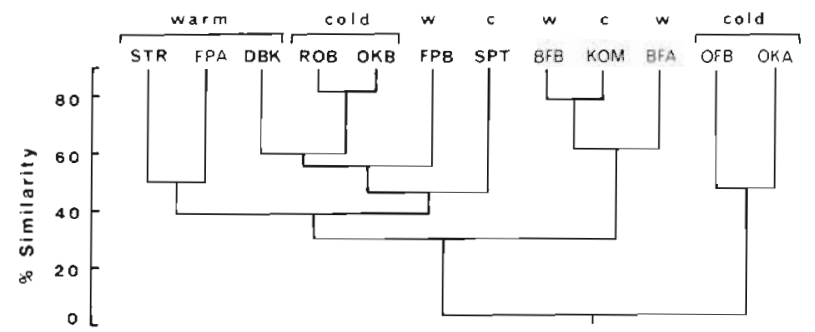

Fig. 6. Results of dendrogram analysis of data. Filter-feeders only, on 12 rocky beaches none of these analyses does grouping occur on the basis of substratum type.

Filter-feeders dominate many of these beaches, and a dendrogram based on data for filter-feeders only (Fig. 6) groups the exposed beaches together. Froggy Pond $\mathrm{A}$ is again exceptional and although sheltered it forms a subgroup of the exposed beaches with Strandfontein. Filter-feeder biomass at Strandfontein is lower than on the remaining exposed shores because the very soft beach-rock substratum there erodes rapidly and is unsuitable for many sedentary species. The sheltered beaches which are not dominated by filterfeeders, are more loosely grouped together at lower levels of similarity.

If the 10 species showing highest biomass at each beach are considered they are found to form between 88.92 and $95.79 \%$ of total biomass on each beach (mean $92.38 \% \pm 2.26$ ). Furthermore, if the 10 species from each of the 12 shores are pooled, a total of only 45 species is involved. A dendrogram analysis on the biomass of these 45 species yields the same groupings as analysis of data on all species, at a slightly higher level of similarity.

\section{Richness and evenness}

Table 1 gives richness and evenness values for the beaches considered. Although any effects of substrate type on the community as a whole are overridden by those of exposure and temperature in the dendrogram analyses, the effects of substratum instability on richness and evenness were obvious. Two of the shores (Oudekraal A and Buffels Bay B) were covered by small boulders ( 30 to $40 \mathrm{~cm}$ in diameter) which become unstable during rough seas. Richness and biomass on these 2 beaches were particularly low, and they both

Table 1. Conditions of sea temperature (W: warm, C: cold), exposure (E: exposed, S: sheltered) and substratum at 12 rocky shores in the Cape of Good Hope. Species richness (S), evenness (J) and mean biomass for each beach as a whole are listed

\begin{tabular}{|c|c|c|c|c|c|c|}
\hline Shore & Temperature & Exposure & Substratum & $\mathrm{S}$ & $\mathrm{J}$ & $\begin{array}{c}\text { Mean biomass } \\
\quad\left(\mathrm{g} \mathrm{m}^{-2}\right)\end{array}$ \\
\hline Sea Point (SPT) & $\mathrm{C}$ & $\mathrm{E}$ & Shale & 98 & 0.86 & 562.60 \\
\hline Robben Island (ROB) & $\mathrm{C}$ & $E$ & Shale & 90 & 0.88 & 461.36 \\
\hline Oudekraal A (OKA) & $\mathrm{C}$ & $S$ & Granite & 43 & 1.40 & 58.94 \\
\hline Oudekraal B (OKB) & $\mathrm{C}$ & $\mathrm{E}$ & Granite & 81 & 1.20 & 959.40 \\
\hline Olifantsbos (OFB) & C & S & Sandstone & 101 & 1.02 & 330.83 \\
\hline Kommetjie (KOM) & $\mathrm{C}$ & $\mathrm{S}$ & Sandstone & 118 & 1.07 & 321.27 \\
\hline Buffels Bay A (BFA) & W & $\mathrm{S}$ & Sandstone & 90 & 0.61 & 387.25 \\
\hline Buffels Bay B (BFB) & w & $\mathrm{S}$ & Sandstone & 63 & 1.22 & 113.08 \\
\hline Froggy Pond A (FPA) & W & $\mathrm{S}$ & Granite & 117 & 0.58 & 544.06 \\
\hline Froggy Pond B (FPB) & w & $E$ & Granite & 99 & 0.63 & 2139.87 \\
\hline Dalebrook (DBK) & W & $\mathrm{E}$ & Sandstone & 137 & 0.78 & 1432.86 \\
\hline Strandfontein (STR) & $w$ & $E$ & Beach rock & 88 & 1.22 & 514.63 \\
\hline
\end{tabular}


displayed a high evenness since no single group of species was able to dominate the community.

No significant differences in richness or evenness were found in comparisons of exposed and sheltered beaches. Similarly cold/warm shore comparisons showed no significant differences. However, in defining the Cape Peninsula as an overlap area between the south and west coast intertidal biota, Stephenson (1944) considered the region of overlap to include False Bay and to extend up the west coast of the peninsula as far as Kommetjie. Richness is signifi- cantly higher in this region than on the remaining west coast beaches (t-test $t_{i} P<0.05$ ).

\section{I-tests and U-tests}

U-tests indicate that a total of 32 species show significant trends in biomass in response to temperature regime (Table 2). Twelve of these species favour cold water (i.e. the west coast) and 20 species favour the warmer waters of False Bay. Of these only 10 are

Table 2. Results of I-tests for indicator species and Mann-Whitney U-tests for biomass trends in comparisons of warm and cold water beaches (Temp.) and of exposed and sheltered beaches (Exp.). The $95 \%$ confidence limit was used in U-tests and a cut-off value corresponding to $P<0.05$ (Field et al., 1982) in I-tests. Species favouring warm water are indicated by $W$, those favouring cold water by $\mathrm{C}$. $\mathrm{E}$ indicates a species favouring exposed conditions, $\mathrm{S}$ a species favouring shelter

\begin{tabular}{|c|c|c|c|c|c|c|c|c|c|}
\hline \multirow{2}{*}{ Species } & \multicolumn{2}{|c|}{ Temp. } & \multicolumn{2}{|c|}{ Exp. } & \multirow{2}{*}{ Species } & \multicolumn{2}{|c|}{ Temp. } & \multicolumn{2}{|c|}{ Exp. } \\
\hline & $\mathrm{I}$ & $\mathrm{U}$ & I & $\mathrm{U}$ & & I & $\mathrm{U}$ & I & $\mathrm{U}$ \\
\hline Algae & & & & & & & & & \\
\hline - Aeodes orbitosa & $\mathrm{C}$ & $\mathrm{C}$ & - & $\mathrm{S}$ & D. huttoni & - & - & - & $\mathrm{E}$ \\
\hline - Arthrocardia sp. & - & - & - & $\mathrm{E}$ & lais pubescens & W & - & - & - \\
\hline - Bifurcaria brassicaeformis & - & - & - & $\mathrm{E}$ & Paridoted ungulata & $\mathrm{C}$ & $\mathrm{C}$ & - & - \\
\hline - Champia lumbricalis & - & $\mathrm{C}$ & - & $\mathrm{E}$ & Amphipoda & & & & \\
\hline - Cladophora capensis & - & $\mathrm{C}$ & - & $\mathrm{E}$ & Hyale diastema & W & W & - & - \\
\hline - Gelidium pristoides & - & - & - & $\mathrm{E}$ & H. grandicornis & $\mathrm{C}$ & $\mathrm{C}$ & - & - \\
\hline - Gigartina radula & - & - & - & $\mathrm{E}$ & Paramoera capensis & - & - & - & $E$ \\
\hline - G. stiriata & C & - & - & - & Tanaidacea & & & & \\
\hline - Gymnogongrus dilatatus & C & $\mathrm{C}$ & - & $\mathrm{S}$ & Leptochelia barnardi & W & W & - & - \\
\hline - Plocamium corralorhiza & - & - & - & $\mathrm{E}$ & Brachyura & & & & \\
\hline - P. cornutum & - & - & - & $E$ & Plagusia chabrus & - & w & - & - \\
\hline - Porphyra capensis & - & $\mathrm{C}$ & - & - & Amphineura & & & & \\
\hline - Pterosiphonia cloiophylla & - & - & - & $\mathrm{E}$ & - Acanthochiton garnoti & - & - & - & $\mathrm{E}$ \\
\hline · Ulva sp. & - & - & - & $\mathrm{E}$ & Pelecypoda & & & & \\
\hline Porifera & & & & & - Aulacomya ater & - & - & - & $\mathrm{E}$ \\
\hline Hymeniacedon perlevis & - & - & - & $\mathrm{E}$ & - Choromytilus meridionalis & - & - & - & $\mathrm{E}$ \\
\hline Anthozoa & & & & & - Perna perna & - & - & - & $\mathrm{E}$ \\
\hline $\begin{array}{l}\text { Bunodosoma capensis } \\
\text { Platyhelminthes }\end{array}$ & - & - & - & $\mathrm{E}$ & $\begin{array}{l}\text { Thecalia concamerata } \\
\text { Gastropoda }\end{array}$ & W & W & - & - \\
\hline Polyclad sp. & - & $\mathrm{C}$ & - & - & Burnupena lagenaria & W & W & - & - \\
\hline Polychaeta & & & & & Crepidula porcellana & W & W & - & - \\
\hline Dodecaceria pulchra & - & $\mathrm{C}$ & - & - & Fissurella mutabilis & - & - & - & $\mathrm{E}$ \\
\hline Euphrosine capensis & - & - & - & $\mathrm{E}$ & Nucella dubia & - & - & - & $E$ \\
\hline Lumbrineris coccinea & - & W & - & - & Oxystele sinensis & W & $w$ & - & - \\
\hline Lysidice natalensis & - & w & - & - & O. variegata & - & $\mathrm{W}$ & - & - \\
\hline Perinereis capensis & W & w & - & - & - Patella barbara & - & W & - & - \\
\hline Platynereis dumerilii & - & w & - & - & - P. cochlear & - & - & - & $\mathrm{E}$ \\
\hline - Pseudonereis variegata & - & - & - & $\mathrm{E}$ & - P. granatina & - & - & - & $\mathrm{S}$ \\
\hline Pomatoleios kraussi & W & w & - & - & - P. granularis & - & - & - & $\mathrm{S}$ \\
\hline Syllis variegata & - & - & - & $\mathrm{E}$ & P. oculus & - & W & - & - \\
\hline Cirripedia & & & & & Pyrene kraussi & - & - & - & $\mathrm{E}$ \\
\hline - Balanus algicola & - & - & - & $E$ & Siphonaria capensis & $\mathrm{C}$ & - & - & - \\
\hline B. maxillaris & - & - & - & $\mathrm{E}$ & Tricolia capensis & - & - & - & $\mathrm{S}$ \\
\hline - Octomeris angulosa & - & - & $\mathrm{E}$ & $\mathrm{E}$ & $T$. neritina & - & W & - & - \\
\hline - Tetraclita serrata & - & - & - & $\mathrm{E}$ & Echinoidea & & & & \\
\hline Isopoda & & & & & - Parechinus angulosus & - & $\mathrm{W}$ & - & - \\
\hline Dynamenella australis & - & $\mathrm{C}$ & - & $\mathrm{E}$ & Tunicata & & & & \\
\hline D. dioxus & W & W & - & - & - Pyura stolonifera & W & $\mathrm{W}$ & - & $E$ \\
\hline
\end{tabular}


amongst the 45 species which dominate intertidal biomass as described above. I-tests analysing which species are indicators of a given temperature regime show that 10 are found only in the warm waters of False Bay and four only on the west coast (Table 2).

I-tests comparing exposed and sheltered sites provide only one indicator species. This is the barnacle Octomeris angulosa, also found by Field and MacFarlane (1968) to be a useful indicator of exposed conditions. No indicator species were found for sheltered conditions. U-tests, however, indicate 36 species showing biomass trends in response to exposure. Almost all of these (30 out of 36) favour exposed rather than sheltered conditions and they include 25 of the 45 species with highest biomass, mainly filter-feeders and algae (Table 2).

\section{DISCUSSION}

Species biomass and community structure on rocky beaches are determined by complex interactions of biotic and abiotic factors. Biotic effects can be profound and complex ranging from grazing effects (e.g. Dayton, 1971, 1975; John and Pople, 1973) and carnivore/prey interactions (e.g. Connell, 1972; Menge, 1976; Menge and Sutherland, 1976) to competition for space (e.g. Paine, 1971). However, biotic effects take place within a basic framework established by the physical environment.

The present study examines how physical factors establish this basic structure, as well as interactions of effects due to different factors. A number of studies have been carried out on the isolated effects of exposure, temperature and substratum as described above. The entire beach biota is generally considered in exposure studies, but many of the investigations of substratum and some of the temperature studies have been autecological and few of these studies have been carried out on a quantitative basis. The dendrograms provided in this study give a quantitative basis for the comparison of beach biota. The difference between exposed and sheltered beaches was most striking and divides the sites examined into 2 groups. Only within these groups are the beaches further divided on the basis of temperature (Fig. 2). When either of these 2 factors was excluded from analysis, grouping occurred on the basis of the other. Analyses of beaches with similar substrata confirm that exposure is the primary factor controlling grouping (Fig. 3). The effects of substratum on the biota as a whole are limited and are overridden by those of temperature and exposure. Substratum may, however, have important autecological effects and, in particular, substrate instability leads to a reduction of species richness.

It is evident that the biota is mixed and may be divided into forms favouring cold and warm water. Although only 14 species were found exclusively on either side of the peninsula, some 32 species showed trends in biomass in response to temperature regime. The 45 species which form approximately $90 \%$ of biomass on all twelve beaches fit well into the regional categories to which they were allocated by Stephenson (1944) and where they do occur outside their regional categories they form only a very small percentage of total biomass. Ten of these 45 species were unclassified by Stephenson and fall into 3 groups: 4 species abundant only on the east coast of the peninsula, in False Bay; 3 species only on the west coast and 3 species which are abundant on both coasts (Table 2). All of these findings agree with previously published distribution records (e.g. Isaac, 1938; Stephenson, 1944; Simons, 1976 etc.). The fact that 6 species of algae exhibited a preference for the Atlantic coast and none for False Bay probably reflects the higher concentration of nutrients available in the upwelled water of the west coast.

Species richness was found to be significantly higher in the overlap region of the west and south coast biota (False Bay to Kommejie); however, there was no significant difference in total beach biomass between warm and cold water beaches. Despite the difference in richness, biomass in the overlap region is not greater than on the west coast. This is because the overlap represents the extreme limit of distribution for many species and they are often present at very low biomass.

Richness and species composition of the communities examined may be largely explained in terms of temperature effects. The degree of wave exposure has an excluding effect on only one species and so interferes minimally with the basic patterns of species composition established by temperature. However, a species need only be represented by a single individual to be present in the community while energy flow through the system is largely dependent on biomass. The Czekanowski coefficient yields dendrograms based on biomass scores and these indicate that the degree of exposure has an overriding effect on the community. Exposure strongly influences the actual biomass of such species as are present rather than determining their presence or absence. This was found for some 36 species, and although this is a small fraction of the total number of species recorded it includes 25 of the 45 species showing highest biomass.

The degree of exposure thus influences the biomass of species forming a large proportion of total biomass. Most of these species (30 out of 36 ) favour exposed conditions resulting in a significantly higher total biomass on exposed beaches $\left(\bar{x}=1011 \mathrm{~g} \mathrm{~m}^{-2}\right)$ than on sheltered beaches $\left(\overline{\mathrm{x}}=292 \mathrm{~g} \mathrm{~m}^{-2}\right.$; $\mathrm{p}<0.05$; see Table 1). The degree of exposure also affects the 
trophic structure of the community with filter-feeders predominating on wave exposed shores: 11 species of filter feeders preferred exposed shores, none sheltered shores (Table 2; McQuaid, 1980; McQuaid and Branch, in prep.).

It appears therefore that temperature induces a framework of species composition on different beaches while exposure influences the biomass of many of the species which dominate on these beaches. Exposure also has a direct effect on the trophic structure of these communities and thus the basic patterns of energy flow through them. Beaches in the Cape Peninsula may be defined firstly according to the degree of exposure they experience and then subdivided according to temperature regime. Within this framework the nature of the substratum has limited effects, concerned mainly with instability or friability leading to impoverishment of the community.

\section{LITERATURE CITED}

Ballantine, W. J. (1961). A biologically-defined exposure scale for the comparative description of rocky shores. Fla Stud. 1: 1-19

Barnes, H., Powell, H. T. (1950). Some observations on the effect of fibrous glass surfaces upon the settlement of certain sedentary marine organisms. J. mar. biol. Ass U. K. 29 (2): 299-302

Bray, J. R., Curtis, J. T. (1957). An ordination of the upland forest communities of southern Wisconsin. Ecol. Monogr 27: $325-349$

Clifford, H. T., Stephenson, W. (1975). An introduction to numerical classification. Academic Press, New York

Connell, J. H. (1972). Community interactions on marine rocky intertidal shores. Ann. Rev. Ecol. Syst. 3: 169-192

Crisp, D. J. (1957). Effect of low temperature on the breeding of marine animals. Nature, Lond. 166: 311-312

Dayton, P. K. (1971). Competition, disturbance and community organization: the provision and subsequent utilization of space in a rocky intertidal community. Ecol. Monogr 41: 351-389

Dayton, P. K. (1975). Experimental evaluation of ecological dominance in a rocky intertidal algal community. Ecol. Monogr. 45: 137-158

Field, J. G. (1969). The use of the information statistic in the numerical classification of heterogenous systems. J. Ecol 57: $565-569$

Field, J. G. (1971). A numerical analysis of changes in the soft bottom fauna along a transect across False Bay. J. exp mar. Biol. Ecol. 7: 215-253

Field, J. G., MacFarlane, G. (1968). Numerical methods in marine ecology. 1. A quantitative 'similarity' analysis of rocky shore samples in False Bay, South Africa. Zool. Afr $3(2): 119-137$

Field, J. G., Clarke, K. R., Warwick, R. M. (1982). A practical strategy for analysing multispecies distribution patterns. Mar. Ecol. Prog. Ser. 8: 37-52

Fricke, A. H., Thum, A. B. (1975). Temperature recording in shallow marine environments. Trans. R. Soc. S. Afr. 41 (4): 351-357

Hällfors, G., Kangas, P., Lappalamen, A. (1975). Littoral benthos of the northern Baltic Sea. III. Macrobenthos of the hydrolittoral belt of filamentous algae on rocky shores in Tvarminne. Int. Revue ges. Hydrobiol. 60 (3): 313-333

Harlin, M. M., Lindbergh, J. M. (1977). Selection of substrata by seaweeds: optimal surface relief. Mar. Biol. 40: 33-40

Hughes, B. W. (1978). The influence of factors other than pollution on the value of Shannon's diversity index for benthic macro-invertebrates in streams. Wat. Res. 12: 359-364

Isaac, W. E. (1938). The geographical distribution of seaweed vegetation in relation to temperature and other factors, with special reference to South Africa. C. $r$ Congr. int. Geogr. Amsterdam 2 (7): 12-28

John, D. M. Pople, W. (1973). The fish grazing of rocky shore algae in the Gulf of Guinea. J. exp. mar Biol. Ecol. 11 $81-90$

Kingsbury, J. M. (1962). The effect of waves on the composition of a population of attached marine algae. Bull. Torrey Bot. Club 89 (3): 143-160

Lewis, J. R. (1964). Ecology of rocky shores. The English Universities Press Ltd, London

McQuaid, C. D. (1980). Spatial and temporal variations in rocky intertidal communities. Ph. D. thesis, University of Cape Town

Menge, B. A. (1976). Organisation of the New England rocky intertidal community: role of predation, competition and environmental heterogeneity. Ecol. Monogr. 46 (4) 355-393

Menge, B. A., Sutherland, J. P. (1976). Species diversity gradients: synthesis of the roles of predation, competition and temporal heterogeneity. Am. Nat. 110: 351-369

Paine, R. T. (1971). A short-term experimental investigation of resource partitioning in a New Zealand rocky intertidal habitat. Ecology 52 (6): 1096-1106

Pielou, E. C. (1969). An introduction to mathematical ecology John Wiley and Sons, New York

Siegel, S. (1956). Nonparametric statistics for the behavioural sciences. McGraw-Hill Book Company Inc., New York

Simons, R. H. (1976). Seaweeds of southern Africa: guidelines for their study and identification. Fish. Bull. S. Afr. 7 $1-113$

Sousa, W. P. (1979). Disturbance in marine intertidal boulder fields: the nonequilibrium maintenance of species diversity. Ecology 60: 1225-1239

Southward, A. J. (1955). On the behaviour of barnacles. 1. The relation of cirral and other activities to temperature. $J$ mar. biol. Ass. U. K. 34: 403-422

Southward, A. J. (1958). Note on the temperature tolerance of some intertidal animals in relation to environmental temperatures and geographical distribution. J. mar. biol. Ass. U. K. 37: 49-66

Stephenson, T. A. (1939). The constitution of the intertidal fauna and flora of South Africa. J. Linn. Soc. Lond. (Zool.) 50: $487-536$

Stephenson, T. A. (1944). The constitution of the intertidal fauna and flora of South Africa. Part II. Ann. Natal Mus. $10(3)$ : $261-358$

Stephenson, W. (1961). Experimental studies on ecology of intertidal communities at Heron Island. II. Effect of substrate. Aust. J. mar. Freshwat. Res. 12: 164-176

Taylor, J. D. (1971). Intertidal zonation at Aldabara Atoll. Phil. Trans. R. Soc, Lond. (B) 260: 173-213

Williams, G. B. (1964). The effects of extracts of Fucus serratus in promoting the settlement of larvae of Spirorbis borealis (Polychaeta). J. mar. biol. Ass. U. K. 44: 397-414

Williams, W. T. (1971). Principles of clustering. Ann. Rev. Ecol. Syst. 2: 303-326 